\title{
PERTUMBUHAN FITOPLANKTON Tetraselmis sp DI WADAH TERKONTROL DENGAN PERLAKUAN CAHAYA LAMPU TL
}

\author{
Anita Padang, Sinta La Djen, Tahir Tuasikal \\ Staf Pengajar UNIDAR-Ambon, e-mail : -
}

\begin{abstract}
ABSTRAK
Tetraselmis sp merupakan jenis fitoplankton dari kelas Clorophyceae yang digunakan sebagai pakan larva ikan dan non ikan. Pertumbuhan Tetraselmis sp sangat dipengaruhi oleh kondisi lingkungan salah satunya adalah cahaya. Intensitas cahaya sangat diperlukan dalam proses fotosintesis, karena hal ini berhubungan dengan jumlah energi yang diterima oleh Tetraselmis sp untuk melakukan fotosintesis. Tujuan dari penelitian ini adalah mengetahui pertumbuhan Tetraselmis sp di wadah terkontrol dengan perlakuan cahaya lampu TL. Penelitian ini dilaksanakan pada bulan Juni 2013 di Laboratorium Pakan Alami UPT Balai Konservasi Biota Laut LIPI Ambon. Penelitian ini dilakukan dengan tiga perlakuan cahaya lampu TL yaitu cahaya 20 Watt, 40 Watt dan 60 Watt. Setiap perlakuan dimasukkan inokulum dengan kepadatan awal $40.000 \mathrm{sel} / \mathrm{ml}$. perhitungan kepadatan dilakukan setiap 24 jam selama 21 hari. Sampel dianalisa dengan menggunakan haemocytometer dan mikroskop NIKON SF dengan pembesaran $200 x$ sebanyak 3 kali ulangan. Pertumbuhan Tetraselmis sp selama 21 hari kultur pada ketiga perlakuan cahaya memperlihatkan hasil yang berbeda. Dimana pencapaian puncak pertumbuhan tertinggi tertinggi pada perlakuan cahaya lampu 60 Watt dan hasil uji ANOVA One Way menunjukkan bahwa ada pengaruh cahaya lampu TL terhadap pertumbuhan Tetraselmis sp.
\end{abstract}

Kata Kunci: Tetraselmis sp, Cahaya Lampu TL, Pertumbuhan, Wadah Terkontrol

\section{PENDAHULUAN}

Plankton adalah organisme mikroskopik yang hidup melayang atau mengapung dalam kolam air dengan kemampuan gerak yang terbatas. Plankton terbagi atas dua kelompok yaitu fitoplankton (plankton nabati) dan zooplankton (plankton hewani) yang merupakan komponen utama dalam rantai makanan ekosistem perairan. Fitoplankton berperan sebagai produsen primer dan zooplankton sebagai konsumen pertama yang menghubungkan dengan biota pada tingkat trofik yang lebih tinggi (Arinardi, 1997).

Fitoplankton sebagai tumbuhan yang mengandung pigmen klorofil mampu melaksanakan reaksi fotosintesis dengan memanfaatkan air, karbondioksida, zat hara dan sinar matahari sehingga menghasilkan senyawa organik. Fitoplankton memberi kontribusi yang besar terhadap produktivitas primer di lautan. Dimana produktivitas primer suatu perairan dapat ditentukan oleh tingkat kelimpahan klorofil di perairan tersebut (Romimohtarto dan Sri Juwana, 2004). Salah satu kelas fitoplankton yang sangat penting di perairan adalah Chlorophyceae.

Tetraselmis sp merupakan jenis dari kelas Clorophyceae yang digunakan sebagai pakan larva ikan dan non ikan serta digunakan dalam pemeliharaan larva ikan laut dengan sistim green water. Tetraselmis sp dapat digunakan sebagai pakan untuk memproduksi Brachionus plicalitis 
secara massal. Tetraselmis sp juga dikonsumsi oleh larva udang, ikan hias dan larva teripang (Isnansetyo dan Kurniastuty, 1995).

Berbagai kegunaan di atas memerlukan ketersediaan Tetraselmis sp yang banyak. Oleh karena itu perlu dilakukan upaya untuk meningkatkan produksi Tetraselmis sp dan salah satu cara yang dapat dilakukan adalah melalui pengkulturan dalam skala laboratorium.

Tingkat pertumbuhan organisme yang dikultur sangat ditentukan oleh ketersediaan unsur hara dan kondisi lingkungan (Sylvester et al, 2002). Kondisi lingkungan yang mempengaruhi pertumbuhan fitoplankton salah satunya adalah cahaya. Intensitas cahaya sangat diperlukan dalam proses fotosintesis karena hal ini berhubungan dengan jumlah energi yang diterima oleh Tetraselmis sp untuk melakukan fotosintesis. Menurut Taw (1990) intensitas cahaya optimum untuk pertumbuhan Tetraselmis sp adalah 2000-10.000 lux. Selanjutnya Hutagaol dalam Hartini (1999) mengemukakan bahwa dengan intensitas cahaya yang besar maka akan semakin baik untuk perkembangan sel alga. Dengan demikian tujuan dari penelitian ini untuk mengetahui pertumbuhan Tetraselmis $\mathrm{sp}$ di wadah terkontrol dengan perlakuan cahaya lampu TL.

\section{METODE PENELITIAN}

2.1. Waktu dan Lokasi Penelitian

Penelitian ini dilaksanakan di Laboratorium Pakan Alami UPT Balai Konservasi Biota Laut Ambon pada bulan Juni 2013.

\subsection{Prosedur Penelitian}

Penelitian diawali dengan persiapan alat dan bahan. Peralatan yang digunakan disterilisasi dengan menggunakan autoclave selama 15 menit pada suhu $121^{\circ} \mathrm{C}$ dengan tekanan $2 \mathrm{~atm}$. Selanjutnya pembuatan media diatom sebagai wadah kultur Tetraselmis sp.

Masukan air laut steril sebanyak $400 \mathrm{ml}$ ke dalam 9 buah erlenmeyer bervolume $500 \mathrm{ml}$, salinitasnya diukur sebesar $31 \%$. Kemudian tambahkan media diatom dan dikocok agar merata. Erlenmeyer yang telah diisi media diatom disterlisasi dalam autoclave selama 30 menit pada suhu $121^{\circ} \mathrm{C}$ dengan tekanan sebesar 2 atm.

Selanjutnya masukkan inokulum dari media kultur murni sebanyak $0,4 \mathrm{ml}$ ke dalam $\quad 9$ buah erlenmeyer. Kemudian diambil $1 \mathrm{ml}$ dari setiap perlakuan dan ulangan untuk dihitung kepadatan sel awal sebanyak $40.000 \mathrm{sel} / \mathrm{ml}$. Erlemeyer diletakan sesuai dengan perlakuan cahaya, yaitu 3 erlenmeyer pada lampu TL 60 Watt, 3 erlenmeyer pada lampu TL 40 Watt dan 3 erlenmeyer pada lampu TL 20 Watt.

\subsection{Metode Analisa Sampel}

Pengamatan pertumbuhan Tetraselmis sp dilakukan dengan perhitungan kepadatan pada sampel setiap 24 jam selama 21 hari dengan menggunakan haemocytometer dan mikroskop NIKON SF pembesaran 200x sebanyak 3 kali ulangan.

\subsection{Analisis Data}

Analisis data pertumbuhan Tetraselmis sp yaitu:

a. Kepadatan

Kepadatan fitoplankton dihitung dengan menggunakan rumus menurut Isnansetyo dan Kurniastuty (1995) yaitu:

$\mathrm{N} \mathrm{x} 10^{4} \mathrm{sel} / \mathrm{ml}$

dimana :

$\mathbf{N}=$ Jumlah rata-rata sel yang terdapat pada kotak bujur sangkar

x $10^{4}=$ Jumlah kepadatan sel sebenarnya pada $1 \mathrm{ml}$ media atau air

b. Analisa Statistik

Guna menguji hipotesis adanya pengaruh cahaya terhadap pertumbuhan Tetraselmis $\mathrm{sp}$ digunakan analisis data One-Way Analisis of Variance (One-Way ANOVA) yang diolah dengan program Microsoft Excel.

\section{HASIL DAN PEMBAHASAN}

3.1. Kepadatan Sel Tetraselmis sp

Hasil pengamatan memperlihatkan kepadatan Tetraselmis sp yang dikultur dengan cahaya berbeda seperti tertera pada Tabel 1 . 
Tabel 1. Kepadatan Tetraselmis sp pada perlakuan Lampu Yang Berbeda (x $10^{4} \mathrm{sel} / \mathrm{ml}$ )

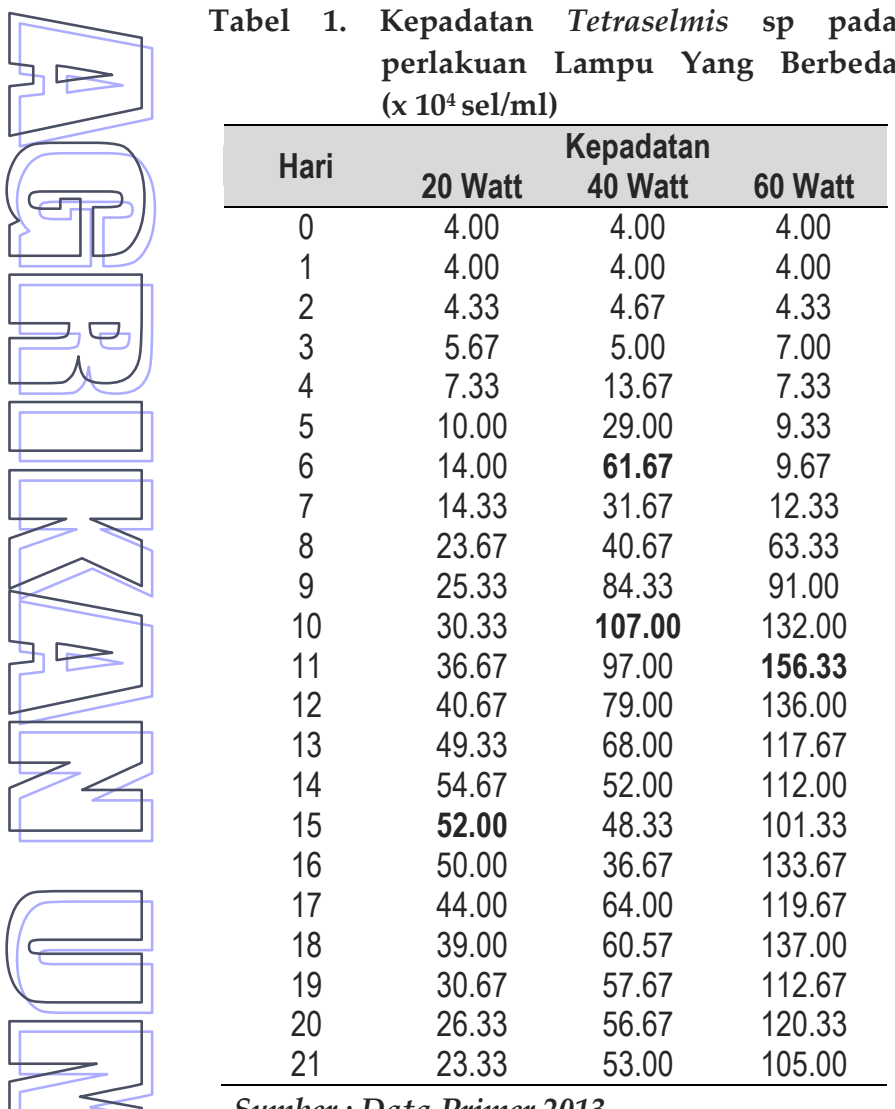

Sumber : Data Primer 2013

Cahaya merupakan faktor penting dalam pertumbuhan mikroalga selain nutrien. Intensitas cahaya sangat diperlukan dalam proses fotosintesis karena hal ini berhubungan dengan jumlah energi yang akan diterima. Dari ketiga perlakuan cahaya terlihat pada hari pertama dan kedua, kepadatan Tetraselmis sp tidak mengalami peningkatan. Ini menunjukkan bahwa pertumbuhan Tetraselmis sp sedang dalam fase leg atau adaptasi. Menurut Fogg (1975) fase leg merupakan fase dimana suatu kultur baru dimulai dengan menginokulasi atau mentransfer sejumlah sel dari medium kultur yang lama ke dalam medium kultur yang baru. Selama fase leg ini pertumbuhan Tetraselmis sp sangat kecil dikarenakan sel-sel sedang beradaptasi dengan lingkungan medium yang baru.

Pada hari ketiga dan keempat telah terjadi pertumbuhan pada semua perlakuan, namun pada perlakuan Cahaya 40 Watt mengalami pertumbuhan lebih cepat. Dimana pada hari keempat kepadatannya sudah mencapai 13,67 x $10^{4} \mathrm{sel} / \mathrm{ml}$, sedangkan untuk perlakuan cahaya 60 Watt dan 20 Watt masing-masing baru mencapai $7,33 \times 10^{4} \mathrm{sel} / \mathrm{ml}$ kemudian berlangsung sampai hari keenam yaitu pada perlakuan cahaya 40 Watt kepadatannya sudah mencapai puncak pertumbuhan I, sementara perlakuan cahaya 60 Watt dan 20 Watt baru bisa berkembang secara normal dengan intensitas cahaya masing-masing.

Hasil pangamatan menunjukan puncak pertumbuhan Tetraselmis sp tertinggi terdapat pada perlakuan cahaya 60 Watt dengan kepadatan sel $156 \times 10^{4} \mathrm{sel} / \mathrm{ml}$ pada hari kesebelas. Diikuti oleh perlakuan cahaya 40 Watt yang memiliki 2 puncak pertumbuhan yang terjadi pada hari keenam dan kesepuluh dengan kepadatan sel $61,67 \times 10^{4}$ dan $107 \times 10^{4} \mathrm{sel} / \mathrm{ml}$, sedangkan puncak pertumbuhan terendah yaitu pada perlakuan cahaya 20 Watt dengan kepadatan $54,67 \quad x \quad 10^{4} \mathrm{sel} / \mathrm{ml}$ pada hari keempatbelas. Untuk lebih jelasnya kepadatan dan pencapaian puncak pertumbuhan dari Tetraselmis sp dapat dilihat pada Gambar 1.

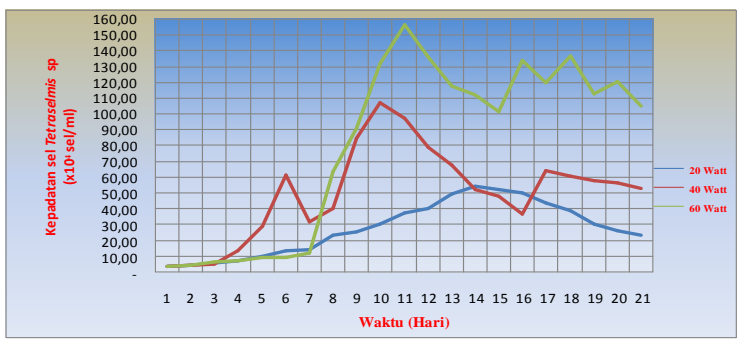

Gambar 1. Grafik Kepadatan Tetraselmis sp (x $10^{4} \mathrm{sel} / \mathrm{ml}$ )

Berdasarkan gambar di atas kepadatan Tetraselmis sp pada ketiga perlakuan terlihat adanya perbedaan puncak pertumbuhan dan jumlah kepadatan sel. Menurut Hutagaol dalam Hartini (1999) bahwa intensitas cahaya yang besar maka akan semakin baik terhadap pertumbuhan sel alga. Grafik di atas menunjukan pada perlakuan cahaya lampu TL 60 Watt memberikan hasil kepadatan tertinggi yaitu sebesar $156 \times 10^{4}$ sel/ml. Kepadatan tertinggi kedua sebesar $107 \mathrm{x}$ $10^{4} \mathrm{sel} / \mathrm{ml}$ pada cahaya lamput TL 40 Watt yang mengalami 2 puncak pertumbuhan yaitu pada hari keenam (puncak 1) dan hari kesepuluh (puncak 2). Hal yang sama juga terjadi pada penelitian Sutomo (2005) yang menggunakan 
lampu TL ternyata pada cahaya 40 Watt puncak pertumbuhan Tetraselmis sp terjadi pada hari keenam dan kesepuluh dengan kepadatan $700.000 \mathrm{sel} / \mathrm{ml}$ (puncak 1) dan $820.800 \mathrm{sel} / \mathrm{ml}$ (puncak 2).

Hal ini menunjukan bahwa adanya dua puncak pertumbuhan bisa saja terjadi karena didukung oleh masih tersedianya nutrien sehingga memungkinkan Tetraselmis $\mathrm{sp}$ melakukan pembelahan sel secara berulangulang dengan memanfaatkan cahaya sebagai sumber energi karena seperti yang diketahui selain salinitas, $\mathrm{pH}$ dan zat hara, cahaya juga merupakan faktor penting dalam pertumbuhan Tetraselmis sp untuk proses fotosintesis (Fabregas et al, 1985).

Perlakuan cahaya lampu TL 20 Watt memiliki kepadatan paling rendah $55 \times 10^{4} \mathrm{sel} / \mathrm{ml}$ dan waktu paling lambat yaitu puncak pertumbuhan pada perlakuan ini baru terjadi pada hari keempatbelas, sedangkan pada penelitian lain oleh Rostini (2007) dengan lampu TL yang sama yaitu 20 Watt, puncak pertumbuhannya lebih cepat yaitu terjadi pada hari kesepuluh dengan kepadatan $752 \times 10^{4}$ sel/ml. Adanya perbedaan waktu pencapaian puncak pertumbuhan dan tingkat kepadatan, diduga karena adanya perbedaan kepadatan awal dimana kepadatan awal pada penelitian ini hanya $4 \times 10^{4} \mathrm{sel} / \mathrm{ml}$ sedangkan kepadatan awal pada panelitian lain yaitu $17 \times 10^{4} \mathrm{sel} / \mathrm{ml}$.

Rendahnya kepadatan serta lambatnya waktu puncak pertumbuhan diperlihatkan oleh perlakuan lampu TL 20 Watt. Sebagaimana menurut Ngadiman dalam Hartini (1999) bahwa kemampuan alga untuk bertahan hidup pada media kultur skala laboratorium yang diberi lampu TL 40 Watt dapat dijadikan dasar atau standar untuk mengkultur alga di laboratorium jika dibandingkan lampu TL 20 Watt.

Pada ketiga perlakuan kultur mempunyai parameter lingkungan yang sama yaitu salinitas $31 \mathrm{ppm}$, suhu ruangan $18^{\circ} \mathrm{C}$, media dan nutrien yang sama, namun dengan intensitas cahaya yang berbeda ternyata mempelihatkan hasil yang berbeda pula. Menurut Lavens dan Sorgeloos (1996) bahwa intensitas cahaya yang diperlukan tiap-tiap jenis tumbuhan dan alga untuk dapat tumbuh secara maksimum adalah berbeda-beda. Intensitas cahaya optimum untuk pertumbuhan Tetraselmis sp adalah 2000-10.000 lux (Taw, 1990) sedangkan kebutuhan akan cahaya bervariasi, tergantung kedalaman kultur dan kepadatannya (Richmond, 2003).

Setelah mencapai puncak pertumbuhan pada fase eksponensial Tetraselmis sp akan menjalani fase penurunan. Walaupun pada perlakuan lamput TL 40 dan 60 Watt menunjukan adanya peningkatan kepadatan pada fase tersebut, tetapi kepadatanya tidak sampai mencapai pada puncak pertumbuhan. Sebagaimana pendapat Burlew (1953) bahwa peningkatan produktivitas sel alga akan terhenti setelah mencapai titik puncak produktivitasnya, yang kemudian akan mengalami penurunan sehubungan dengan berjalannya waktu.

Adanya peningkatan kepadatan sel pada lamput Tl 40 dan 60 Watt pada fase penurunan diduga karena ada individu baru yang masih membelah dengan sisa nutrien dan intensitas cahaya yang tersedia. Sebagimana menurut Isnansetyo dan Kurniastuty (1995) penurunan populasi pada fase kematian setelah mencapai puncak populasi maksimal diduga disebabkan karena berkurangnya nutrien sehingga menyebabkan proses fotosintesis tidak berjalan dengan sempurna.

\subsection{Pengaruh Cahaya Terhadap Kepadatan Tetraselmis sp}

Pengaruh cahaya terhadap kepadatan Tetraselmis sp yang dianalisis dengan One Way ANOVA dapat dilihat pada Tabel 2. Berdasarkan hasil ANOVA dengan tingkat kepercayaan 95\% menunjukkan bahwa nilai $F_{\text {hitung }}=\mathbf{9 0 . 8 8 8}>F_{\text {tabel }}=5.1433$ demikian juga dengan tingkat kepercayaan $99 \%$ nilai $F_{\text {hitung }}=$ $90.888>F_{\text {tabel }}=10.925$. Hal ini berarti bahwa intensitas cahaya sangat berpengaruh terhadap pertumbuhan. Dengan nilai $F_{\text {hitung }}>F_{\text {tabel, }}$ maka dilakukan uji lanjut berdasarkan nilai CV. Nilai CV yang didapatkan dari 3 perlakuan intensitas cahaya ini adalah 8.9769 atau $\mathrm{CV}>0,5$. Sebagaimana dikemukakan oleh Hanafiah (2002) dan Khouw (2008) bahwa jika nilai CV $=5-10 \%$ maka akan dilakukan uji Beda Nyata Terkecil. 
Tabel 2. Hasil One Wway ANOVA Kepadatan Tetraselmis sp

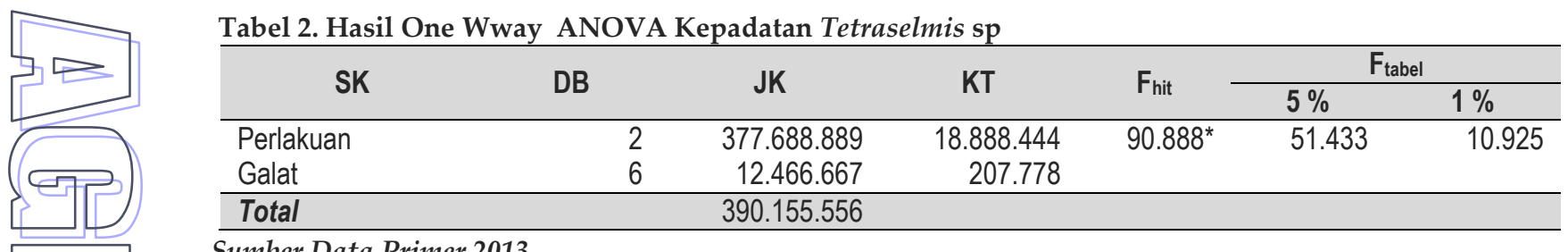

Sumber Data Primer 2013

Ket : ** berbeda sangat nyata

Tabel 3. Hasil Uji Beda Nyata Terkecil Kepadatan Tetraselmis sp

\begin{tabular}{rrc}
\hline Perlakuan & Rata-Rata & $\begin{array}{c}\text { N Non } \\
\text { Signifikant } \\
\text { Ranges }\end{array}$ \\
\hline 60 Watt & 77 & $3 \mathrm{a}$ \\
40 Watt & 48.333 & $3 \mathrm{~b}$ \\
20 Watt & 27 & $3 \mathrm{c}$ \\
\hline
\end{tabular}

Ket: Angka yang diikuti oleh huruf yang sama artinya tidak berbeda dan angka yang dikuti oleh huruf yang berbeda artinya sangat berbeda

Tabel di atas menunjukan bahwa setiap perlakuan cahaya lampu TL berbeda sangat nyata terhadap tingkat intensitas cahaya yang lain. Dimana nilai rata-rata 77 pada perlakuan cahaya lampu TL 60 Watt jauh berbeda dengan nilai rata-rata 40 Watt dan 20 Watt. Demikian juga pada perlakuan cahaya 40 Watt memiliki nilai rata-rata 48.333 yang berbeda dengan 60 Watt dan 20 Watt .

Jika nilai rata-rata setiap perlakuan dibandingkan antara satu dengan yang lain yaitu pada perlakuan 60 Watt selisih nilai rata-ratanya adalah 28,667 dan 50. Untuk perlakuan 40 Watt selisihnya adalah 21,333, maka terdapat perbedaan rata-rata terbesar pada perlakuan 60 Watt. Hal ini menunjukkan dalam penelitian ini, cahaya 60 Watt memberikan pengaruh yang lebih tinggi terhadap kepadatan Tetraselmis $\mathrm{sp}$ dibandingkan dengan dua perlakuan lainya.

\section{PENUTUP}

\subsection{Kesimpulan}

Berdasarkan hasil penelitian ini dapat disimpulan bahwa :

1. Intensitas cahaya mempengaruhi pertumbuhan Tetraselmis sp dan lebih dari satu kali puncak pertumbuhan.

2. Intensitas cahaya 60 Watt memberikan kepadatan tertinggi terhadap kepadatan sel Tetraselmis sp dibandingkan perlakuan yang lain.

3. Parameter yang diukur dalam penelitian ini yang meliputi parameter suhu dan salinitas masih menunjukkan kondisi yang turut mendukung pertumbuhan Tetraselmis sp.

4.2. Saran

Disrankan guna mendapaan kepadatan Tetraselmis sp yang tinggi, sebaiknya diberikan intensitas cahaya 60 Watt dan bagi stok bibit/sediaan sebaiknya digunakan intensitas cahaya 40 Watt

\section{DAFTAR PUSTAKA}

Arinardi, O. H. 1997. Status Pengetahuan Plankton di Indonesia. Oseanologi dan Limnologi di Indonesia 30: 63-95.

Burlew, J. S. 1953. Current Status of Large-Scale of Algae Culture. In: Alga Culture from Laboratory to Pilot Plant. Carnegie Institute of Washington. Washington.

Fabregas, J., C. Herrero., J. Abalde., and B. Cabezaz. 1985. Growth, Chlorophyll a and Protein of The Marine Microalga Isochrysis galbana in Batch Culture with Different Salinities and High Nutrient Consentration. Aquaculture $50: 43-56$.

Fogg, G. E. 1975. Algae Cultures And Phytoplankton Ecology. 2 Edition. The University Of Wisconsin Presc. Madison. London. 175 p. 
Hartini. 1999. Pertumbuhan Clamydomonas sp pada Intensitas Cahaya yang Berbeda. Skripsi Fakultas Perikanan dan Ilmu Kelautan. Universitas Sam Ratulangi Manado. Hanafiah, A.K. 2002. Rancangan Percobaan Teori dan Aplikasi. Edisi Tiga. PT Raja Grafinda Persada Jakarata.

Isnansetyo, A. dan Kurniastuty. 1995. Teknik Kultur Phytoplankton dan Zooplankton Pakan Alami untuk Pembenihan Organisme Laut. Kanisius. Yogyakarta.

Khouw, A.S. 2008. Metode dan Analisa Kuantitatif Dalam Biologi Laut.

Lavens, P. dan Sorgeloos P. (eds). 1996. Manual on the Production and Use of live Food for Aquaculture. FAO Fisheries Technical Paper. No. 361. Rome: Food and Agriculture Organization of the United Nations.

Richmond, A. 2003. Handbook of Microalgae Culture Biotechnology and Applied Phycology. Blackwell Publishing

Rostini, I. 2007. Kultur Fitoplankton Chlorella sp dan Tetraselmis chuii Pada Skala Laboratorium. Universitas Padjadjaran. Jatinagor.

Romimohtarto, K dan Sri Juwana. 2004. Meroplankton Laut : Larva Hewan Laut yang Menjadi Plankton. Penerbit Djambatan, Jakarta : 215 hal.

Sylvester, B., D. Nelvy dan Sudjiharno. 2002. Persyaratan Budidaya Fitoplankton dan Zooplankton.

Sutomo. 2005. Kultur Tiga Jenis Mikroalga (Tetraselmis sp, Chlorella sp, dan Chaetoceros gracilis) dan Pengaruh Kepadatan Awal Terhadap Pertumbuhan Chaetoceros gracillis di Laboratorium. Pusat Penelitian Oseanografi LIPI, Ambon.

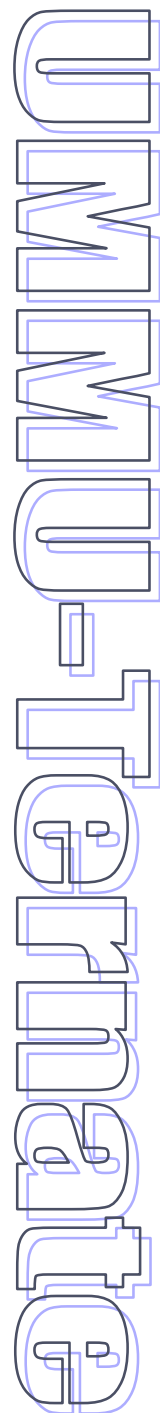

Taw, N. 1990. Petunjuk Pemeliharaan Kultur Murnian Massal Mikroalga. Proyek Pengembangan Udang, United Dations Development Programme, Food and Agrikultur Organitation of the United 